\title{
THE XTH INTERNATIONAL CONGRESS OF THE HISTORY OF SCIENGE
}

The Xth International Congress of the History of Science will be held in the United States of America, 26 August-2 September 1962. Opening sessions of the Congress will be held at Cornell University, Ithaca, New York, and the concluding sessions will be held at the American Philosophical Society, Philadelphia, Pennsylvania. The President of the Congress is Professor Henry Guerlac of Cornell University. The Secretary of the Congress is Professor C. Doris Hellman.

All inquiries should be addressed to The Secretary, Xth International Congress of the History of Science, Cornell University, Ithaca, New York (U.S.A.). Those wishing to receive bulletins concerning the congress are requested to communicate with the Secretary.

\section{Obituary}

ROBERT RUTSON JAMES, F.R.G.s. ( I 88 I-I 959)

Mr. James, who was Consulting Ophthalmic Surgeon to St. George's Hospital, was also a distinguished medical historian particularly interested in the early history of his speciality and of his medical school. His writings were of an admirable precision and included the following publications: The School of Anatomy adjoining St. George's Hospital, 1830-1863, (1928), Studies in the History of Ophthalmology prior to the year I800, (1933) and, with J. H. Bloom, Medical Practitioners in the Diocese of London, I529-1725, (1935). He also contributed occasional historical notes to the Lancet and other journals. His unpublished works comprised two notable transcriptions-that of the Barber Surgeons Company Register, I 540-1 745, which he deposited in the library of the Royal College of Surgeons, and that of the Students' Admission Register of St. George's Hospital Medical School, I 759-1918, annotated copies of which he gave to the College and the School. The unique collection of medical bookplates which he carefully gathered was also given to the College of Surgeons, an institution which, like the Medical School, is greatly indebted to his assiduity and generosity. Mr. James died on 28 September 1959, having lived in retirement at Woodbridge. 